\title{
Finnsheep and their utilization in crosses with the Merino under range conditions of South-Africa
}

\author{
J. C. GREEFF and J. H. HOFMEYR \\ Animal and Dairy Science Research Institute, Irene, RSA
}

\begin{abstract}
Two field trials were performed at two localities in a semiarid region to evaluate the performance of Finn $(\mathrm{F}) \times$ Merino $(\mathrm{M})$ crossbred females. The trials involved $781 \mathrm{~F}$ $\times \mathrm{M}$ ewes and $657 \mathrm{M}$ ewes. Ile de France, S.A. Mutton Merino, Dohne Merino, M, and F $\times M$ rams were used for matings. The $F \times M$ ewes were superior to $M$ ewes in lambing- $\%$, especially after mating as lambs, and the fecundities were 187 and $107 \%$, resp. Multiple lambs of $\mathrm{F} \times \mathrm{M}$ ewes had better survival rates than those of $\mathrm{M}$ ewes. Lambs born from $\mathrm{F} \times \mathrm{M}$ ewes grew faster, had a larger weaning mass, over $10 \%$ longer stables, ca. $2 \mathrm{~mm}$ thicker fibres, $30 \%$ lower clean fleece weights, and a little less crimps $/ 25 \mathrm{~mm}$ than those born from $\mathrm{M}$ ewes. Thus, $\mathrm{F} \times \mathrm{M}$ seemed to provide a suitable and acceptable composite showing remarkable adaptability to harsh environmental conditions. The results from the $\mathrm{F} \times \mathrm{M}$ wool and its special qualities can be regarded as useful attributes. Establishment of a composite $\mathrm{F} \times \mathrm{M}$ female line appeared well-founded.
\end{abstract}

Index words: Finnsheep, S.A. Mutton Merino, crossbreeding, mutton production, wool production, reproduction, daily gain, synthetic

\section{Introduction}

Improvement in the reproductive rate through accelerated lambing and/or higher fecundity rate of the ewe flock offers the greatest single opportunity for increasing the biological efficiency of lamb as well as mutton and wool production. The infusion of high fertility genes through crossbreeding has proved to be the most rapid breeding procedure to bring about such biological efficiency and for this reason Finnsheep (F) has been introduced into the sheep flocks of many countries. Numerous trials have been conducted in recent years to evaluate its suitability in crossbreeding with local breeds and different environmental conditions.

F were imported into the RSA in 1968 and have been used in several crossbreeding experiments $(3,4)$. A small nucleus experimental flock is also maintained to observe the performance of pure-breds under local conditions.

This short paper covers the preliminary 
results of two field trials set up at two localities in a semi-arid region to evaluate the performance of $\mathrm{F} \times$ Merino (M) crossbred females. As is so often the case it is not always possible to plan and conduct field trials as well as in formal experiments, but in spite of certain limitations useful results do accrue. M controls were included in both trials.

Both trials were launched during an extended drought period which lasted from the previous winter season till last year (1987 July), and the performance of the animals, particularly in the first trial initiated in 1983, suffered seriously as a result of poor nutritional conditions.

Animals in the second trial were supported by irrigated pastures and were not notably affected by the drought conditions.

\section{Experimental}

First trial. This trial involved $600 \mathrm{~F} \times \mathrm{M}$ crossbred ewes and $600 \mathrm{M}$ ewes, subdivided into groups and inseminated with semen from Ile de France (IdF), South African Mutton Merino (SAMM) and Dohne Merino (DM) rams. This was followed by group mating of the $\mathrm{M}$ and $\mathrm{F} \times \mathrm{M}$ ewes with $\mathrm{M}$ and $\mathrm{F} \times \mathrm{M}$ rams. Owing to deteriorating environmental conditions, these latter groups were treated slightly better during the last three weeks of gestation.

Second trial. In the second trial $181 \mathrm{M} \times$ $\mathrm{M}$ and $57 \mathrm{M}$ ewes were involved in a comparative performance evaluation.

\section{Results}

\section{Trial 1}

Reproduction: Owing to environmental conditions, lambing percentages for natural mating following AI were poor in both groups but clearly in favour of the $\mathrm{F} \times \mathrm{M}$ with $61 \%$ vs. M $48 \%$. Fecundity was $118 \%$ for $\mathrm{F} \times$ $\mathrm{M}$ and $102 \%$ for $\mathrm{M}$.

Survival rate of lambs: No significant differences of survival rate occurred between groups in the case of single born lambs, but the survival rate from birth to weaning was significantly $(\mathrm{P}<0,05)$ better for lambs born as multiples to $\mathrm{F} \times \mathrm{M}$ ewes (Table 1).

Growth: Lambs from $\mathrm{F} \times \mathrm{M}$ ewes had significantly $(\mathrm{P}<0,01)$ higher growth rates from birth to five weeks of age and significantly ( $P$ $<0,01)$ higher weaning masses than lambs born from $\mathrm{M}$ ewes at 100 days of age (Table 2 ). The differences between sire-breed groups were not significant except for the Dohne Merino.

Wool at 9 months of age: Except for the Mutton Merino $\times \mathbf{M}$, Dohne Merino $\times \mathbf{M}$ and Ile de France $\times$ M, although not significant, had on average slightly lighter fleeces than their related crosses born from $\mathrm{F} \times \mathrm{M}$ ewes (Table 3). As expected the $\mathrm{M}$ and $\mathrm{M}$ offspring produced the finest fibres while $\mathrm{F} \times$ $\mathrm{M}$ offspring produced longer wool staples.

\section{Trial 2}

Reproduction: Of the $181 \mathrm{~F} \times \mathrm{M}$ ewes exposed to rams $(\mathrm{F} \times \mathrm{M})$ between $4-10$ months of age, $65 \%$ lambed before 12 months of age with a fecundity rate of $136 \%$ (Table 4). None of the $\mathrm{M}$ ewes lambed. $\mathrm{F} \times \mathrm{M}$ ewes lambed within a period of 38 days.

All ewes (both groups) were again exposed to $\operatorname{rams}(\mathrm{F} \times \mathrm{M})$ at 18 months of age after some culling on wool faults had been applied (Table 5).

Significant differences were found between: lambing \% (92 vs. $75 \%$ in favour of $\mathrm{F} \times \mathrm{M})$; and fecundity (187 vs. $107 \%$ also in favour of $\mathrm{F} \times \mathrm{M})$.

Survival rate of lambs: The first group of offspring of the $\mathrm{F} \times \mathrm{M}$ ewes had a survival rate of $77 \%$ (Table 4 ) at weaning (100-days) and the second group, $98,9 \%$ vs. the M's $80,6 \%$ (Table 5).

Growth: Lambs of the $\mathrm{F} \times \mathrm{M}$ ewes were significantly $(\mathrm{P}<0,01)$ heavier at weaning (100-days) than lambs born from $M$ ewes (19,2 vs. $14,9 \mathrm{~kg})$. 
Table 1. Survival rate $(\%)$ of lambs at different stages from birth to weaning (Trial 1).

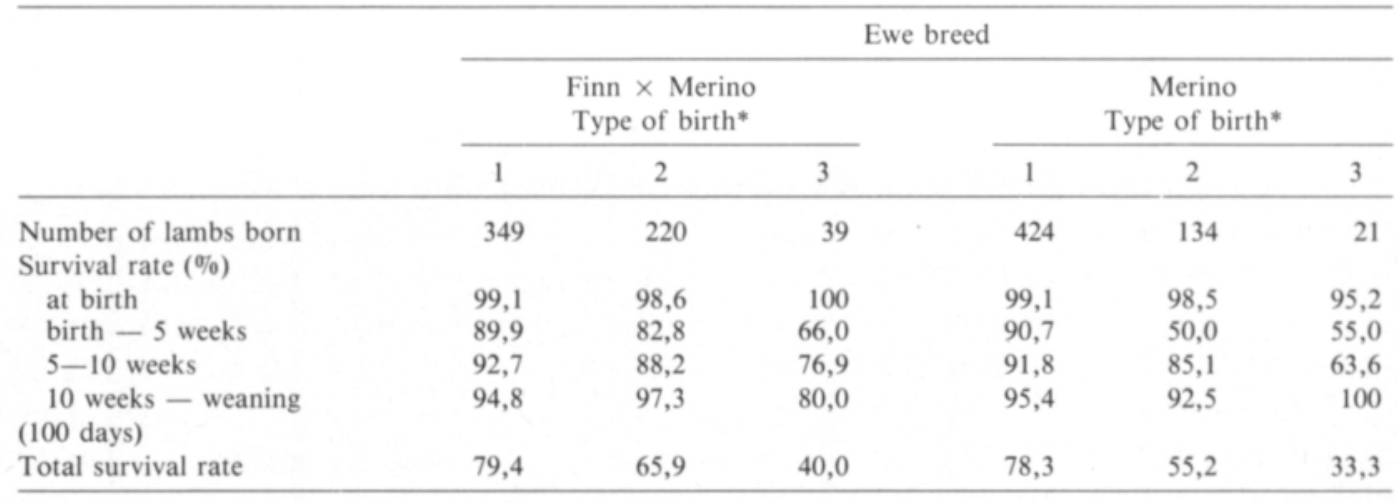

$* 1$ = Singleton; 2 = Twins; 3 = Triplets

Table 2. Average daily gain (ADG) from birth to 5 weeks of age and weaning mass of crossbred lambs (g/day) ${ }^{2}$ (Trial 1).

\begin{tabular}{|c|c|c|c|c|}
\hline \multirow[t]{2}{*}{ Ram breed } & \multicolumn{4}{|c|}{ Ewe breed } \\
\hline & $\mathbf{n}$ & Finn $\times$ Merino & $\mathrm{n}$ & Merino \\
\hline ADG (birth -5 weeks of age: g) & & $(x \pm$ S.E. $)$ & & $(x \pm$ S.E. $)$ \\
\hline Ile de France & 147 & $299 \pm 9,3^{a}$ & 171 & $277 \pm 2,4^{a}$ \\
\hline Dohne Merino & 24 & $269 \pm 38,6^{b}$ & 95 & $266 \pm 21,5^{b}$ \\
\hline SA Mutton Merino & 108 & $290 \pm 6,2^{a}$ & 89 & $276 \pm 8,6^{a}$ \\
\hline Merino' & 83 & $295 \pm 16,5^{a}$ & 37 & $274 \pm 16,3^{a}$ \\
\hline Finn $\times$ Merino $^{1}$ & 98 & $292 \pm 3,1^{a}$ & 44 & $274 \pm 6,7^{a}$ \\
\hline \multicolumn{5}{|l|}{ Weaning mass at 100 days $(\mathrm{kg})$} \\
\hline Ile de France & 98 & $18,8 \pm 0,59^{a}$ & 127 & $16,7 \pm 0,13^{a}$ \\
\hline Dohne Merino & 9 & $16,2 \pm 3,79^{\circ}$ & 66 & $16,1 \pm 1,34^{a}$ \\
\hline SA Mutton Merino & 79 & $18,5 \pm 0,35^{a}$ & 54 & $16,7 \pm 0,59^{a}$ \\
\hline Merino' & 61 & $18,8 \pm 0,95^{a}$ & 19 & $14,3 \pm 1,35^{b}$ \\
\hline Finn $\times$ Merino $^{1}$ & 71 & $18,2 \pm 0,19^{a}$ & 30 & $15,1 \pm 0,42^{b}$ \\
\hline
\end{tabular}

1 Lambs born from Merino and Finn $\times$ Merino rams received slightly different treatments. See text.

${ }^{2}$ Means with different superscripts in the same column differ significantly from each other.

Table 3. Wool characteristics of crossbred lambs shorn at 9 months of age in $1987 . .^{1}$ (Trial 1).

\begin{tabular}{|c|c|c|c|c|c|c|}
\hline Breed/Genotype 2 & $\mathrm{n}$ & $\begin{array}{c}\text { Clean } \\
\text { fleece } \\
(\mathrm{kg})\end{array}$ & $\begin{array}{l}\text { Staple } \\
\text { length } \\
(\mathrm{mm})\end{array}$ & $\begin{array}{c}\text { Fibre } \\
\text { diameter } \\
\text { (micron) }\end{array}$ & $\begin{array}{c}\text { Crimps } \\
\text { per } \\
25 \mathrm{~mm}\end{array}$ & $\begin{array}{c}\text { Crimp } \\
\text { deviation }\end{array}$ \\
\hline \multicolumn{7}{|l|}{ Lambs } \\
\hline Merino & 21 & $1,40^{b}$ & $88,3^{a}$ & $15,7^{\mathrm{a}}$ & $13,3^{\text {ac }}$ & $79^{a}$ \\
\hline $\mathrm{F} / \mathrm{M} \times \mathrm{M}$ & 25 & $1,24^{a}$ & $100,5^{\mathrm{d}}$ & $16,4^{a}$ & $13,6^{\mathrm{ac}}$ & $83^{\mathrm{ab}}$ \\
\hline $\mathrm{M} \times \mathrm{F} / \mathrm{M}$ & 50 & $1,45^{b}$ & $101,8^{\mathrm{d}}$ & $17,2^{b}$ & $12,5^{a}$ & $84^{\text {ab }}$ \\
\hline $\mathrm{F} / \mathrm{M} \times \mathrm{F} / \mathrm{M}$ & 37 & $1,24^{a}$ & $106,9^{a}$ & $17,7^{\mathrm{b}}$ & $12,8^{\mathrm{a}}$ & $87^{b}$ \\
\hline $\mathrm{IdF} \times \mathrm{M}$ & 111 & $1,38^{\mathrm{b}}$ & $91,1^{\mathrm{e}}$ & $18,2^{\mathrm{b}}$ & $16,0^{4}$ & $99 d$ \\
\hline $\mathrm{IdF} \times \mathrm{F} / \mathrm{M}$ & 125 & $1,42^{b}$ & 96,9 & $19,9^{\circ}$ & $14,4^{c}$ & $103^{e}$ \\
\hline $\mathrm{SAMM} \times \mathrm{F} / \mathrm{M}$ & 128 & $1,26^{a}$ & $93,4^{c}$ & $18,2^{\mathrm{b}}$ & $14,2^{\mathrm{bc}}$ & $94^{c}$ \\
\hline $\mathrm{SAMM} \times \mathrm{M}$ & 61 & $1,31^{\mathrm{a}}$ & $80,5^{b}$ & $16,8^{\mathrm{ab}}$ & $14,3^{\mathrm{bc}}$ & $87^{\mathrm{b}}$ \\
\hline $\mathrm{DM} \times \mathrm{F} / \mathrm{M}$ & 16 & $1,38^{\mathrm{b}}$ & $103,3^{\mathrm{d}}$ & $18,2^{\mathrm{b}}$ & $13,0^{\mathrm{ab}}$ & $91^{\mathrm{b}}$ \\
\hline $\mathrm{DM} \times \mathrm{M}$ & 59 & $1,33^{\mathrm{ab}}$ & $80,2^{b}$ & $16,4^{n}$ & $13,2^{\text {ab }}$ & $82^{a}$ \\
\hline
\end{tabular}

1 Means with the same superscript in the same column do not differ significantly from each other.

2 Ram breed mentioned first.

${ }^{3}$ Duerden standard $=100$. 
Wool: Ewes were shorn at 11 months of age (Table 6). As in Trial 1 the $\mathrm{M}$ produced significantly $(\mathrm{P}<0,01)$ more clean wool than the $\mathrm{F} \times \mathrm{M}$ crossbreds, the latter producing an amount equivalent to $71 \%$ of the $\mathrm{M}$.

\section{Conclusion/Remarks}

In a country such as South Africa, where both lamb and wool production are important, environmental circumstances dictate the relative emphasis placed on the two commodities.

In general, extensive range conditions favour wool production and here the $\mathrm{M}$ is likely to remain the dominant breed in production systems. This breed consitutes approximately $65 \%$ of the current sheep population of 35 million (1). The $\mathrm{M}$ is, however, not suitable for intensive lamb and wool production systems $(2,4)$ and with growing emphasis on more intensive production systems, particularly in areas of higher potential it is obvious that a more suitable genotype is required.

Results obtained from a comprehensive crossbreeding experiment and several field trials, including the two reported on in this paper, have led to the conclusion that the halfbred $\mathrm{F} \times \mathrm{M}$ provides a suitable and acceptable composite showing remarkable adaptability to even comparatively harsh environmental conditions.

The favourable results obtained from the crossbred $(\mathrm{F} \times \mathrm{M})$ wool and its special qualities (low felting and low creasing features) are regarded as useful attributes.

There appears to be sufficient evidence available now to support the establihment of a composite $\mathrm{F} \times \mathrm{M}$ female line for deployment in the industry, certainly under conditions where favourable nutritional conditions exist.
Table 4. Reproduction of Finn $\times$ Merino and Merino ewes exposed to rams from 4-10 months of age (Trial 2).

\begin{tabular}{lcc}
\hline & \multicolumn{2}{c}{ Ewe breed } \\
\cline { 2 - 3 } & $\begin{array}{c}\text { Finn } \times \\
\text { Merino }\end{array}$ & Merino \\
& 181 & 57 \\
\hline Number of ewes available & 65,7 & - \\
Lambing (\%) & 136,1 & - \\
Fecundity (\%) & 77,1 & - \\
Survival rate of weaning' $(\%)$ & $29,4-30,9 \quad(27,8-28,6)^{2}$ \\
Mass at conception $(\mathrm{kg})$ & 29,4
\end{tabular}

1 Lambs weaned per total number of lambs born.

${ }^{2}$ Mass range concurrent with Finn $\times$ Merino conception.

Table 5. Reproduction of $\mathrm{F} \times \mathrm{M}$ and $\mathrm{M}$ ewes mated at 18 months of age and survival rates of their lambs (Trial 2).

\begin{tabular}{|c|c|c|}
\hline & \multicolumn{2}{|c|}{ Ewe breed } \\
\hline & $\begin{array}{l}\text { Finn } \times \\
\text { Merino }\end{array}$ & Merino \\
\hline $\begin{array}{l}\text { Number of ewes available } \\
\text { Ewe mass at mating }\end{array}$ & 157 & 37 \\
\hline $\mathrm{kg} \pm$ S.E. & $47,8 \pm 0,33$ & $43,2 \pm 0,68$ \\
\hline Lambing $(\%)$ & 92,4 & 75,5 \\
\hline Fecundity $(\%)$ & 186,9 & 107,1 \\
\hline Survival rate at birth' $(\%)$ & 99,3 & 86,6 \\
\hline $\begin{array}{l}\text { Survival rate from birth } \\
\text { to weaning }{ }^{2}(\%)\end{array}$ & 98,9 & 80,6 \\
\hline
\end{tabular}

1 Lambs born alive per total number of lambs born.

${ }^{2}$ Lambs weaned per number of lambs born alive.

Table 6. Wool characteristics of the $\mathrm{F} \times \mathrm{M}$ and $\mathrm{M}$ (Trial 2) measured at 11 months of age.

\begin{tabular}{lcc}
\hline & \multicolumn{2}{c}{ Genotype } \\
\cline { 2 - 3 } & Finn $\times$ & Merino \\
& Merino \\
\hline Number of ewes shorn (n) & 168 & 55 \\
Mass at shearing (kg) & 38,7 & 33,3 \\
Greasy fleece mass (kg) & 3,4 & 4,8 \\
Clean yield (\%) & 69,6 & 71,7 \\
Clean fleece mass (kg) & 2,4 & 3,4 \\
Staple length (mm) & 114,7 & 106,8 \\
Crimps per 25 mm & 8,9 & 9,0 \\
Fibre diameter (micron) & 21,3 & 19,9 \\
Crimp deviation & 92 & 86 \\
\hline
\end{tabular}




\section{References}

1. Abstract Of Agricultural. Statistics, 1988. Directorate of Agricultural Economics and Marketing. Pretoria. ISBN 0621114235.

2. Bonsma, F.N., 1939. Factors influencing the growth and development of lambs with special reference to crossbreeding of Merino sheep for fat lamb production in South Africa. Univ. Pretoria Publ., Sec. 1., NO. 48, Rep. South Africa.

3. Hofmeyr, J.H., Ueckermann, L., Kün, G.P. \& Roux, C.Z., 1974. Intensive sheep production:
Preliminary observations on the effect of crossbreeding as exhibited by the production qualities of certain Merino crosses. Proc. of 5th Congress. S. Afr. Genet. Soc., Stellenbosch Univ. February, 1974. $140-144$.

4. Hofmeyr, J.H. 1980. Implications of experimental results of crossbreeding sheep in the Republic of South Africa. Proc. World Congr. Sheep and Beef Cattle Breed. Vol I. Ed. R A Barton and W C Smith. The Dunmore Press, New Zealand. 